\title{
CL-Dataveg - a database of Chilean grassland vegetation
}

\author{
Miguel Alvarez, Bodo Maria Möseler, Cristina San Martín, Carlos Ramírez \& Javier \\ Amigo
}

\begin{abstract}
Grassland vegetation in temperate Chile is dominated by European plant species. Since those plant communities got established spontaneously, they offer us the possibility to study invasion (dispersal) dynamics at the synecological level. In this ongoing project we are collecting published relevés of the temperate and Antarctic regions of Chile, storing them in a TURBOVEGdatabase (CL-Dataveg; GIVD ID SA-CL-001). Also relevés from the Argentinean Patagonia are included. The main aims of this project are to develop a summarizing classification of the grassland vegetation in the geographical range mentioned above and to confirm its assignment into the class Molinio-Arrhenateretea (included until now in the Agrostidion chilensis Oberdorfer alliance, 1960). Secondary aims are to describe the geographic patterns of distribution, to compare the South American plant communities with their European counterparts, and to identify missing surveys. The future inclusion of all available data of the vegetation in Chile into CL-Dataveg is also considered.
\end{abstract}

Keywords: Agrostidion chilensis; anthropogenic vegetation; Molinio-Arrhenatheretea; phytosociology.

\section{CL-Dataveg}

Scope: All available relevés of grassland vegetation including the sub-Mediterranean, temperate, and Antarctic belts in South Chile and South Argentina.

Status: ongoing capture

Period: $1975-2008$

Database manager(s): Miguel Alvarez (malvarez@uni-bonn.de)

Owner: Dr. Miguel Alvarez (private)

Web address: http://www.ipe.uni-bonn.de/pflanzenernaehrung/mitarbeiter/m_alvarez

Availability: according to a specific agreement

Online upload: no Online search: no

Database format(s): TURBOVEG, MS Access

Export format(s): TURBOVEG, MS Access

Publication: [NA]

Plot type(s): normal plots

Non-overlapping plots: 650

Total plot observations: 650

Plot-size range: $1-100 \mathrm{~m}^{2}$

Countries: CL: $100.0 \%$

Estimate of existing plots: 1,500

Number of sources: 18

Forest: [NA] — Non-forest: [NA]

Guilds: all vascular plants: $100 \%$

Environmental data: [NA]

Performance measure(s): cover: $100 \%$

Geographic localisation: small grid (not coarser than $10 \mathrm{~km}$ ): $100 \%$

Sampling periods: 1970-1979: 8.7\%; 1990-1999: 74.1\%; 2000-2009: 17.2\%

Information as of 2012-07-12; further details and future updates available from http://www.givd.info/ID/SA-CL-001

Miguel Alvarez* (malvarez@uni-bonn.de), Bodo Maria Möseler (moeseler@uni-bonn.de)

Vegetation Ecology, INRES, University of Bonn, Nussallee 9, 53115 Bonn, GERMANY

Cristina San Martín (csanmart@uach.cl)

Instituto de Ciencias Ambientales y Evolutivas, Universidad Austral de Chile, Valdivia, CHILE

Carlos Ramírez (cramirez@uach.cl)

Departamento de Ecología, Pontificia Universidad Católica de Chile, Santiago, CHILE

Javier Amigo (javier.amigo.vazquez@usc.es)

Botany, Faculty of Pharmacy, University of Santiago de Compostela, Santiago de Compostela, SPAIN

*Corresponding author 